\title{
ENSURING SAFE CYBERSPACE FOR CHILDREN: AN ANALYSIS OF THE LEGAL IMPLICATIONS OF SOCIAL MEDIA USAGE IN MALAYSIA AND SINGAPORE*
}

\author{
Md. Zahidul Islam** \\ Sonny Zulhuda*** \\ Nor Hafizah Mohd Badrol Afandi***** \\ Mohamed Affan Shafy ${ }^{* * * * * *}$
}

\begin{abstract}
Easy accessibility of electronic devices connected to the internet and the widespread usage of the internet in every aspect of modern lives have made the use of social media an indispensable part of society. These technologically driven and completely-internet dependence means of living have brought detrimental implications as much as they have benefited lives. Each day more and more children are introduced to the internet and its benefits, either at home as a means of entertainment, or at school as a means of education. However, these opportunities provide avenues for the children to explore the ever-expanding vastness of the internet, leading to exposure of indecent materials, and accessing and participating in websites not meant for the usage by underage children. The glorification of social media websites through targeted
\end{abstract}

This paper is funded by the International Islamic University Malaysia (IIUM) under the Research Initiative Grant Scheme, under the Project ID: No. P-RIGS18-023-0023.

** Assistant Professor at the Department of Civil Law, Ahmad Ibrahim Kulliyyah of Laws, International Islamic University Malaysia. Email: zahidul@iium.edu.my.

*** Associate Professor at the Department of Civil Law, Ahmad Ibrahim Kulliyyah of Laws, International Islamic University Malaysia. Email: sonny@iium.edu.my.

**** Assistant Professor at the Department of Civil Law, Ahmad Ibrahim Kulliyyah of Laws, International Islamic University Malaysia. Email: hafizah@iium.edu.my.

${ }^{* * * * *}$ Ph.D. Candidate at the Department of Civil Law, Ahmad Ibrahim Kulliyyah of Laws, International Islamic University Malaysia. Email: shafy.mv@gmail.com . 
advertisements and peer pressure adds to the already worsening crises of social media abuse through unlawful means. This article examines the protective measures taken by the authorities in Malaysia and Singapore to protect children in these two countries from the internet and social media related issues. The data is acquired doctrinally from library sources and the finding of this article could be extended to other areas of protecting young children from the harms of the internet.

Keywords: safe cyberspace, social media, children, Malaysia and Singapore, laws of internet.

\title{
MEMASTIKAN RUANG SIBER YANG SELAMAT UNTUK KANAK-KANAK: SUATU ANALISA TENTANG IMPLIKASI PENGGUNAAN MEDIA SOSIAL DI MALAYSIA DAN SINGAPURA
}

\begin{abstract}
ABSTRAK
Akses mudah ke peranti elektronik yang disambungkan ke internet dan penggunaannya secara meluas dalam setiap aspek kehidupan moden hari ini menjadikan media sosial sebagai sebahagian aspek yang penting dalam interaksi masyarakat. Kehidupan yang banyak bergantung kepada teknologi internet telah membawa kepada pelbagai implikasi, samada yang baik atau yang buruk. Setiap hari ramai kanak-kanak terdedah kepada dunia internet sama ada di rumah sebagai alat permainan atau di sekolah sebagai alat pembelajaran. Akan tetapi, peluang sebegini menyediakan ruang kepada kanak-kanak untuk meneroka perkembangan internet yang meluas, yang membawa kepada pendedahan terhadap bahan-bahan tidak senonoh, dan mengakses dan mengambil bahagian dalam laman web yang tidak tidak sepatutnya digunakan oleh kanak-kanak di bawah umur. Pengagungan laman web media sosial melalui iklan bersasar dan pengaruh rakan sebaya menambahkan lagi tekanan kepada krisis penyalahgunaan media sosial melalui cara yang menyalahi undang-undang yang semakin teruk. Artikel ini meneliti langkah-langkah pencegahan yang dapat dilakukan oleh pihak berkuasa di Malaysia dan Singapura untuk melindungi kanakkanak di negara-negara itu dari isu berkaitan internet dan media social. Data diperolehi secara doktrinal dari sumber perpustakaan dan penemuan artikel ini boleh diperluaskan ke bahagian lain untuk melindungi kanak-kanak dari bahaya internet.
\end{abstract}

Kata kunci: ruang siber selamat, media sosial, kanak-kanak, Malaysia dan Singapura, undang-undang internet. 


\section{INTRODUCTION}

Different social media websites may take different approaches to handling, accepting, and operating their websites. However, a few commonalities are found as most of these websites are designed to collect personal data. The website would act as an avenue to establish social connections with other potential individuals. ${ }^{1}$ The advent of the first modern-day social media websites began in the years 1997 and 1998 with the likes of 'sixdegrees.com' where it was for the first time that the internet users were allowed to browse through an array of other users' profiles and to make 'friends'. Another early internet social site, 'classmates.com', was centered on keeping the social circle within the users' school, and allowing users to have an accessible network. It was not until a few trials later that a fully-fledged website with present-day social media options subsequently took over the internet. It is noteworthy to mention that the website 'sixdegrees.com' had managed to attract massive followers. At first, these websites did not seem to revolve around everyday ordinary lives. However, within a few short years, new websites such as 'Myspace', 'Bebo', 'Facebook' etc. made household names in social media. As a result, it might be impossible now to live without adopting any form of social media for various usages. Despite cultural and social differences, social networking websites have interwoven with the fabric of the societies due to the affordability and availability of technological advances in a consistent fashion. ${ }^{2}$ By the data available from 2006 in the United States alone, Pew Research found that $93 \%$ of the children aged between 12 and 17 had access to the internet and more websites were being made accessible as children were heavily involved in these social websites. ${ }^{3}$

1 Danah M Boyd and Nicole B Ellison, "Social Network Sites: Definition, History, and Scholarship," Journal of Computer-Mediated Communication 13, No. 1 (2007): 210-30.

2 Yang Feng and Wenjing Xie, 'Teens' Concern for Privacy When Using Social Networking Sites: An Analysis of Socialization Agents and Relationships with Privacy-Protecting Behaviors," Computers in Human Behavior 33 (2014): 153-62.

3 Amanda Lenhart, Mary Madden, Aaron Smith and Alexendra Macgill, Teens and Social Media, Internet \& Technology, Pew Research Center (2007) https://www.pewresearch.org/internet/2007/12/19/teens-andsocial-media/ (accessed $20^{\text {th }}$ November 2019). 


\section{METHODOLOGY}

Through a doctrinal methodology, this article examines the legal provisions relating to the protection against harmful threats towards who are children online and using social media networks. The target groups of this study are children in Malaysia and Singapore. The legislative frameworks in both countries are analysed and discussed and a conclusion is derived on the effective enforcement of such laws protecting children in cyberspace. The article also identifies the similarities and differences in the legislations of both countries and looks into modern and new threats to children in the ever-evolving social media atmosphere.

\section{EFFECTS OF SOCIAL MEDIA ON CHILDREN}

Keeping a social media profile for the sole reason of keeping up with friends and family has changed when more options to meet and befriend total strangers from around the world were made possible by these websites. Often these websites are marketed either as a common interest group or as cultural, or sometimes fringe communities around the world. The sophistication of modern social media is such that of a multi-faceted exposure of one's self whether through writing about one's daily activities or interests, sharing intimate or personal videography, utilizing these websites, or marketing and income making opportunities. $^{4}$

Studies have shown that the usage of social media has a distinct effect on the user's behaviour, though the effect may be different based on the user's gender, age, or nationality. According to Khoo, the psychological and other effects directly related to social media usage and personal data issues have been studied extensively by researchers. ${ }^{5}$ It was found that there were instances where personal data have been hacked from social media accounts and made publicly available by hackers. Sometimes the victims were blackmailed and forced to do the

4 Joseph Bonneau and Sören Preibusch, "The Privacy Jungle: On the Market for Data Protection in Social Networks," in Economics of Information Security and Privacy (Springer, 2010). 121-67.

5 Christopher S G Khoo, "Issues in Information Behaviour on Social Media," LIBRES: Library and Information Science Research Electronic Journal 24, No. 2 (2014): 75. 
bidding of these culprits just so that they could protect their data from being leaked to the public. Such as the months-long 'virtual enslavement' of 124 women including 16 underage girls in South Korea, where the victims were asked to send compromising photos through fraudulent advertisements and later blackmailed into sending more violent or degrading acts on themselves. The data of the victims were exposed and sold by the perpetrators for thousands of dollars online. ${ }^{6}$ This very act destroys the reputation and in the worst cases destroys the lives of the victims. As more and more data such as photographs, locations, statuses, and others are shared with a click of a button, the process entails a very dangerous path as this data could be used by a perpetrator to locate and cause extremely damaging destruction to the targeted person, especially children who are the biggest victims of social media impacts. ${ }^{7}$

This pattern of potential exploitation is further increased when parents of these children share private photos with friends through social media, whilst they are unaware of the safety precautions, they could use this to prevent these kinds of unfortunate mishaps, which might lead to these private photos and moments being watched by undesired eyes. Most social media websites, especially the mainstream ones come with settings that can be used to hide the private family moments from the outside world, and only to be shared with a certain set of preferred users. However, as a result of being unaware of these safety mechanisms in place, these photos and videos of children may be openly exposed to the world. It has to be noted that a photo or a video acquired with the wrong intention by a malicious threat would be extremely detrimental and at unfortunate times have proven to be fatal for the victims. ${ }^{8}$

6 Sangmi Cha, "South Korea's Moon Calls for Full probe into online sexual blackmail ring", Reuters, March 23, 2020, https://in.reuters.com/article/southkorea-sexcrime/south-koreas-mooncalls-for-full-probe-into-online-sexual-blackmail-ring-idINKBN21A1Q7 (accessed 13 August 2020).

7 Waseem Akram and R Kumar, "A Study on Positive and Negative Effects of Social Media on Society," International Journal of Computer Sciences and Engineering 5, No. 1 (2017): 351-54.

$8 \quad$ Waseem Akram and R Kumar, "A Study on Positive and Negative Effects of Social Media on Society," International Journal of Computer Sciences and Engineering 5, No. 1 (2017): 351-54. 
As the world is getting more technologically advanced, a photo taken by a mobile phone or a modern digital camera can attach geolocation data such as the precise GPS (Global Positioning System) data of the location of the photo or the video was taken. This increases the threat for the potential victims exponentially if these photos fall to the wrong hands. As such paedophiles, identity thieves, human traffickers, or other dangerous criminals would have the potential to get the exact location of where and when the picture was taken from a seemingly harmless family photograph shared on the internet. It is imperative for these very reasons that parents or guardians of these children to be aware of the potential dangers of cyberspace and also to have the basic online safety information on protecting themselves and their loved ones from becoming a victim of social media and its abusers. $^{9}$

It has also been reported that many social media platforms do not conform to laws and is seen to work in ways to circumvent the barriers. ${ }^{10}$ These companies somehow tend to keep monitoring the private data of children for their business-related benefits. Previous studies conducted have shown that the correlation between exposure to risk and the actual harm factor in children with the usage of the internet medium, either by exposure to sexual imagery, meeting strangers online, or even online bullying, are very real and the damaging effects are rather detrimental and visible. ${ }^{11}$ According to the EU kids' online report, $30 \%$ of children have met with people they only knew online. ${ }^{12}$

A study conducted in Ghana in 2015 on the academic performance patterns of 1,508 students concluded that the usage of social media has affected students' academic performance negatively and that the correlation between the usage of social media and the

$9 \quad$ Waseem Akram and R Kumar, "A Study on Positive and Negative Effects of Social Media on Society," International Journal of Computer Sciences and Engineering 5, No. 1 (2017): 351-54.

10 Tijana Milosevic and Sonia Livingstone, Protecting Children Online?: Cyberbullying Policies of Social Media Companies (MIT Press, 2017). 172.

11 Sonia Livingstone and Leslie Haddon, Children, Risk and Safety on the Internet: Research and Policy Challenges in Comparative Perspective (Policy Press, 2012). 9.

12 Patti M Valkenburg and Jessica Taylor Piotrowski, Plugged in: How Media Attract and Affect Youth (Yale University Press, 2017). 236. 
performance in academic activities was apparent. The volunteers of this study mentioned that the usage of social media was for a duration on average between 30 minutes to 3 hours every day. The study also focused on getting an answer as to why students would opt for the usage of social media daily and found that over $86.8 \%$ of them used it for talking to people over the internet and only $6.4 \%$ of the students used social media for academic purposes. ${ }^{13}$ This research finding relating to 'online chatting' is a concern as it indicates that most of the time spent by students on social networking websites were spent on services that have the potential to be harmful, and these services are easily available on the internet.

In a much more focused study conducted in South Africa on the effect of social media usage on female students in developing countries, it was concluded that social media affects the mental health of female students and it provides needless and confusing information to these students. ${ }^{14}$ Most of the time the information is not genuine. The study also found that prolonged social media use could waste valuable time and is often addictive. ${ }^{15}$ Overall, the study made recommendations after its findings that social media should be oriented towards the specific culture of the user and the students should abstain from blindly following what they see and read on social media. It also made recommendations on the importance of limiting the time spent on these social media websites. It has to be noted that even though the study concluded with the view that appropriate use of social media services is beneficial, the detrimental effects are visible in the very core as they challenge and change beliefs of the cultural and social aspect of an individual student's lifestyle. The study also recommended for the content creators to avoid using detrimental approaches such as in

13 M Owusu-Acheaw and Agatha Gifty Larson, "Use of Social Media and Its Impact on Academic Performance of Tertiary Institution Students: A Study of Students of Koforidua Polytechnic, Ghana.," Journal of Education and Practice 6, No. 6 (2015): 94-101.

14 Joshua Ebere Chukwuere and Precious Chibuike Chukwuere, "The Impact of Social Media on Social Lifestyle: A Case Study of University Female Students," Gender and Behaviour 15, No. 4 (2017): 9966-81.

15 Joshua Ebere Chukwuere and Precious Chibuike Chukwuere, "The Impact of Social Media on Social Lifestyle: A Case Study of University Female Students," Gender and Behaviour 15, No. 4 (2017): 9966-81. 
content creation and the promotion of these products and services online. ${ }^{16}$

It has been found that social media abuse and its impact are directly linked to adverse health effects, societal implications, and impact on the education of the users. For instance, it is mentioned by Akram and Kumar, self-diagnosis based on the information available on social media is detrimental to health and is mentioned as a negative effect of social media. It is found that social media adversely affects not only the physical wellbeing of the student but it also psychologically demotivates and renders the users redundant. The paper also mentioned that since acquiring data from social media and internet sources is very fast and easy, the time students spent on studying has reduced, causing a detrimental impact on their education. As a direct result of the lack of human contact, there is a possibility that these students will have a hard time in the real world or a face to face environment. It goes on to warn that the content available on some of these social media websites were either embellished, such as the usage of photoshop to portray a specific type of body image as better, leading to children to strive to achieve impossible targets or to negatively influence the children to be involved in risky sexual behaviour. ${ }^{17}$

Safety for children on social media cannot be ensured just by making rules and regulations alone. It needs to be practically enforced inclusively to all related parties including parents, teachers, friends, family, and anyone concerned with the welfare of the child. Those in responsible positions need to be cautious and extremely careful with how and what is being shared and how social media is utilized by children. The government could pass legislation with severe punishments for the abusers. However, if users of social media are unaware of the ways they could keep themselves and their loved ones protected from these potential threats, then the work of the government and these laws will be futile and would not generate desirable results. In today's ever technologically inclined society, users should be aware

16 Joshua Ebere Chukwuere and Precious Chibuike Chukwuere, "The Impact of Social Media on Social Lifestyle: A Case Study of University Female Students," Gender and Behaviour 15, No. 4 (2017): 9966-81.

17 Akram and Kumar, "A Study on Positive and Negative Effects of Social Media on Society." International Journal of Computer Sciences and Engineering 5, No. 1 (2017): 351-354. 
of the proper usage of the websites and who to reach if they find themselves falling victim to online threats.

A study conducted by Mensah and Nizam in 2016 on the effects of social media usage on the academic performance among tertiary students in Malaysia concluded that the usage of social media can have a detrimental effect on users, especially those students who were significant without time management skills. This study also found that the usage of social media led to detrimental health, as it can cause addiction. It was found that some of the addicted users neglected their natural routine of taking care of themselves in preference to social media. $^{18}$

According to the Digital Intelligence Institute impact report 2018 which provides an annual report summarizing the state of online safety and digital citizenship of 8 to12 year olds around the world, $57 \%$ of children in Malaysia and almost 54\% of the children in Singapore have been exposed to one or more forms of cyber risk. These risks include cyberbullying, gaming addiction, online sexual behaviour, and interaction with strangers on the internet. This report which collected data from 29 countries also found that $56 \%$ of the children who participated in this study were either involved or exposed to the aforementioned risks. ${ }^{19}$

Due to the concerns over under-regulated social-media to prevent abuse and misuse of online activities by children, ${ }^{20}$ many

18 Sandra Okyeadie Mensah and Ismail Nizam, "The Impact of Social Media on Students' Academic Performance-A Case of Malaysia Tertiary Institution," International Journal of Education, Learning and Training 1, No. 1 (2016): 14-21.

19 "Outsmart the Cyber-Pandemic, Empower Every Child with Digital Intelligence," 2018, https://www.dqinstitute.org/2018dq_impact_report/. (retrieved on $20^{\text {th }}$ November 2019).

20 Wonsun Shin and Nurzali Ismail, "Exploring the Role of Parents and Peers in Young Adolescents' Risk Taking on Social Networking Sites," Cyberpsychology, Behavior, and Social Networking 17, No. 9 (2014): 578-83. 
countries-globally have begun to enact domestic law on the matter, including that of Malaysia and Singapore, as examined below. ${ }^{21}$

\section{SOCIAL MEDIA CONTROL AND REGULATIONS IN MALAYSIA}

Malaysia's internet infrastructure is highly developed. However, to mitigate issues posed by modern technological advances, Malaysia has legislated several laws. By the year 2010, the country had already developed over 10 major pieces of legislation or made amendments to legislation that could address any potential cyber offenses or social media related issues. Among the relevant laws include the Computer Crimes Act 1997 and the Personal Data Protection Act of 2010.

To control the internet and social media as well as to protect children from their negative influence, a regulatory commission known as the Communications and Multimedia Commission (MCMC) was set up, and the Communications and Multimedia Act 1998 (CMA 1998) was adopted. It has to be noted that the CMA 1998 is under the management of the Energy, Water and Communications Ministry of Malaysia, which assumes discretionary authority on taking action related to media usage. ${ }^{22}$ The MCMC along with the CMA 1998 conjointly regulates taboo contents with the MCMC acting as the primary internet regulatory commission for Malaysia.

The introduction of the CMA 1998 allowed the government to monitor and control not only the analog media, but the digital media along with broadcasting, usage, and services provided by the internet. The MCMC is empowered with a legal mandate of protecting, safeguarding as well as seeing that the laws and regulations related to communications and multimedia are enforced and implemented..$^{23}$ The mandate includes the issuance, revocation and amendment of

21 Juriah Abdul Jalil, "Combating Child Pornography in Digital Era:; Is Malaysian Law Adequate to Meet the Digital Challenge," Pertanika Journal of Social Science and Humanities 23 (2015): 137-52.

22 Jonathan Zittrain and John G Palfrey, Access Denied: The Practice and Policy of Global Internet Filtering (Oxford Internet Institute, 2007). 326327.

23 Saodah Wok and Shafizan Mohamed, "Internet and Social Media in Malaysia: Development, Challenges and Potentials," in The Evolution of Media Communication (IntechOpen, 2017). 45-64. 
telecommunication license whilst trying to achieve the objectives of governmental national cyber policies. In addition, the MCMC also has the legal mandate to maintain aspects of freedom of expression in the cybersphere under section 3(3) of the CMA 1998, where it gives assurance to the public that the purpose of the broadcast and multimedia laws are not to censor the internet.

During the year 2008, the MCMC reprimanded a popular website 'Malaysia Today' on the account that its activities were bordering on insensitive incitement. The minister at the time claimed that section 263 of the CMA 1998 gave the ministry authority to take action based on public safety and national security. However, less than a day later, the actions against the website were revoked, following public decry. ${ }^{24}$

In relation to children, the main law adopted in Malaysia for children's protection is the Child Act 2001. The Act defines a child as a person under the age of eighteen years and restricts media reporting regarding child matters. For example, in a situation where a child is convicted in relation to a criminal offense, the Act prohibits the media from disclosing the child's personal information including the name and any such other identifiable information.

In addition to the Child Act, the protection of children involving social media is also regulated by other legislations such as the Printing, and Presses and Publications Act 1984. The Act protects the children by prohibiting the handling of child pornography in any form or method. This Act confers the authority to other government ministries to reprimand and take relevant action against all forms of biased negativity which would imperil the public and the national interests. Actions that are allowed to be taken by the authorized ministries include the total and complete ban of material in any broadcast or information distribution medium within Malaysia.

Another related law on children protection is the Personal Data Protection Act 2010 (PDPA) which was enacted to secure the privacy right of individuals in the commercial context. The purpose of this law is "to regulate and protect the process of personal data from being

24 Saodah Wok and Shafizan Mohamed, "Internet and Social Media in Malaysia: Development, Challenges and Potentials," in The Evolution of Media Communication (IntechOpen, 2017). 45-64. 
misused through commercial transactions and matters relating thereto". The sole purpose in other words would be to defend against the misuse of personal information and to keep the personal data safe and prevent its abuse. ${ }^{25}$ It is a mandatory requirement under the PDPA for anyone handling personal data to conform with the seven principles mentioned in part II of the PDPA. As a general principle, Section 6 of the Act mentions that if a data user wants to use or process personal data about an individual, he has to get consent from the data subject. Section 7 requires the acquiring of a written notification by the data collector from the subject on why and how their personal data is being collected, and for what purpose. Section 8 discusses the disclosure principle. It mentions that personal data shall not be disclosed without the consent of the data subject for any purpose other than the purpose which was initially disclosed at the time of collection of data. In addition, the data shall not be disclosed to any other party without prior consent from that individual. The security principle of the Act mentions that the parties utilizing personal data of individuals shall be responsible to ensure security, reliability, and integrity. It is the responsibility of the entities utilizing personal data to ensure all necessary measures are in place to prevent any misuse and abuse whether accidental, or on purpose, the peruse, loss or alterations of data, or any such act which would lead to the disclosure of unconsented personal data to unauthorized parties.

Section 10 of PDPA provides that the data user will not be allowed to keep personal data for periods longer than is essentially necessary for the purpose where the data was first acquired or collected. The law also mandates them to have the data removed upon the exhaustion of the authorized data-related activity. Section 11 of PDPA relates to the data using an entity to maintain the data intact and in an up-to-date manner whilst at the same time ensuring the integrity of the data.

The access principle mentioned that the data subject shall be allowed to access, correct, delete, or amend personal data when it is wrong. Therefore, taking special consideration when handling datarelated to children, the law mandates handlers of these sensitive personal data to observe full duty and care when handling these

25 Lauren A Matecki, "Update: COPPA Is Ineffective Legislation-Next Steps for Protecting Youth Privacy Rights in the Social Networking Era," Nw. JL \& Soc. Pol'y 5 (2010): 369. 
personal data. It is also the responsibility of the data handlers to promote awareness programs among the users on the detrimental effects and the potential impact of social media's mishandling to prevent issues such as phishing attacks.

\section{SOCIAL MEDIA CONTROL AND REGULATIONS IN SINGAPORE}

In 2019, The New Paper of Singapore conducted research on the usage of social media websites by children. The focus of the research was to identify how informed the parents were with the minimum age requirements and the utilization of social media by the children themselves. Despite the low sampling group, it nevertheless represented an alarming discovery as illustrated in Table 1 below that most parents' perception of the usage of social media by their children was not at par with Singapore's government laws and regulations. Out of 20 parents who participated in the survey 14 parents were not aware of the minimum age requirement. ${ }^{26}$

26 Daniel Burgess and Erlina Calubayan, Parents Unaware of Social Media Age Restrictions, July 8, 2019, https://www.tnp.sg/news/singapore/parents-unaware-social-media-agerestrictions (retrieved on $20^{\text {th }}$ November 2019). 
Table 1: Social Media Usage by Children, Parental Awareness and Accountability

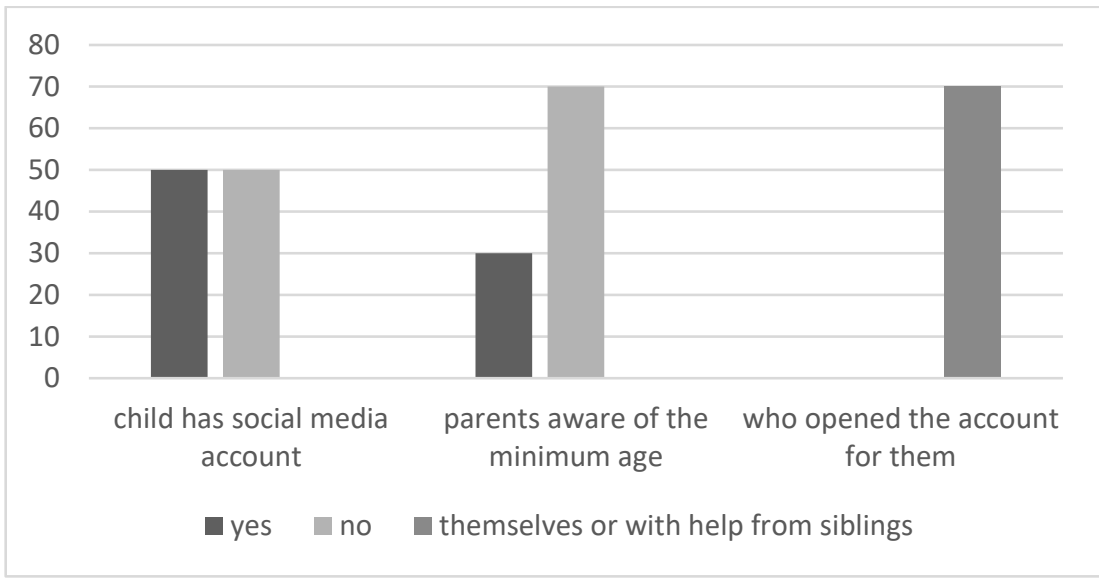

Source: Burgess and Calubayan, The New Paper 2019. ${ }^{27}$

To control the internet-based social media as well as to protect the children from the negative influence of social media, many laws have been adopted by the Singapore government. ${ }^{28}$ The Info Communications Media Development Authority (IMDA) is an authority under the Ministry of Communications and Information (MCI) with main functions to develop and regulate the converging information, communications, and media sectors. One of the relevant laws is the Broadcasting Act 1996 which empowers the minister of MCI to ban the disclosure of any directions to censor content. ${ }^{29} \mathrm{On}$ the part of IMDA, its scope includes content regulation aiming to protect the young. The main priorities of IMDA are to focus on concerns relating to contents that are harmful to children in addition to other public interest issues such as religion, race, and pornographic materials

27 Daniel Burgess and Erlina Calubayan, Parents Unaware of Social Media Age Restrictions, July 8, 2019, https://www.tnp.sg/news/singapore/parents-unaware-social-media-agerestrictions (retrieved on $20^{\text {th }}$ November 2019).

28 Lai-Yun Ho, "Raising Children in Singapore: A Paediatrician's Perspective," Ann Acad Med Singapore 38 (2009): 158-62.

29 Garry Rodan, "The Internet and Political Control in Singapore," Political Science Quarterly 113, No. 1 (1998): 63-89. 
online. It has to be noted that the mandate of IMDA does not include regulating internet messaging and emails conducted within Singapore.

In 2018, the Public Order and Safety (Special Powers) Act was approved by the Parliament, which has a big role to protect children from social network sites. It authorizes relevant government agencies to put out a blanket prohibition such as a complete and total blocking of service, and form of communications during a time of a 'serious incident' such as a terrorist attack or other forms of public interest issues in the likes of either a peaceful protest or public demonstrations. Other related laws are the Newspaper and Printing Presses Act 1974 and the Broadcasting Act 1994 which cover the internet, grant powers to ministers to fill in the details through articulated subsidiary regulations, such as website licensing and registration rules. The Sedition Act 1958 and the Political Donation Act 2000 are also applicable to restrict online communication.

According to Harassment Act 2014, using "threatening, abusive, or insulting" acts which are inflammatory and may cause "harassment, alarm, or distress" is valid for penalization if deemed necessary. Anyone who is a victim of these forms of abuse has the right to legal remedies such as protection orders, injunctions, and the banning of materials detrimental to the victim from being published. At the same time, the victim is allowed to seek damages from the perpetrator for the defamatory or inflammatory statements or publications.

To protect children and young people, Singapore has adopted The Children and Young Person Act 2001. Under this Act, a child is a person below the age of 14 years and a young person means a person who is 14 years of age or above but below the age of 16 years. This Act imposes a restraint on publication of broadcasting leading to the identification of a child or young person as a child or young person who is the subject of any investigation under this Act. ${ }^{30}$

The Personal Data Protection Act 2012 also plays an important role to protect children in Singapore. Part IV of the Act discusses the

30 Trudy Hui Hui Chua and Leanne Chang, "Follow Me and like My Beautiful Selfies: Singapore Teenage Girls' Engagement in SelfPresentation and Peer Comparison on Social Media," Computers in Human Behavior 55 (2016): 190-97. 
collection, use, and disclosure of personal data. According to this Act, an organization shall not collect, use, or disclose personal data about an individual unless the individual gives his consent under this Act. This Act also mentions that an organization shall not obtain or attempt to obtain consent for the collection, use or disclose personal data by providing false or misleading information. Section 2(3) of the Act specifically prohibits sharing and providing personal information on individuals despite having the personal data even with the consent of the individual, should specific issues arise. They include foreseeable detrimental to the safety, physical and mental health of the individual, or revealing personal data of an individual to a third party, or if the organization holding the personal information data finds that revealing personal information to the individual themselves might be detrimental to their physical or mental well-being or if it may cause immediate or grave harm to that individual. The law specifically mandates the organizations to verify not only the data they receive but also the data they retain, retrieve, and distribute. This provision itself is enough to hold data-holding organizations to be more responsible in dealing with data especially in relation to children.

Section 23 of the Act requires organizations to make reasonable efforts to ensure that personal data that they collected from an individual is accurate and complete. This provision is enforced or observed to the full extent by the organizations to prevent a major number of false consensual data provided by individuals, especially children pretending to sign up for online services on social media, or by providing false information. Section 23 stresses that the verification is bound to be conducted with reasonable effort especially if the organization decides to use the personal data in a way that would affect the individual. This is the case with social media platforms where information related to individuals, including photographs, location, personal contact information is made freely available for anyone online. Section 25 of the Act requires any obtained personal information to be removed as soon as they have a reasonable assumption that the data collected does not serve the reason it was collected in the first place. This provision can be construed that as soon as an organization holding the data could not verify the personal information provided or if the data collected is found to be illegal then the organization should not hold the data in question. 
Another notable feature of the Personal Data Protection Act 2012 is the way it prohibits personal data collected within Singapore to be transferred outside the territory of Singapore unless the location in question has set-up and enforced similar personal data protection laws. This prohibition is a means of guarantee that even with the consent of the individual whose data is being held, if the destination of the data is a place without a data protection law akin to that of Singapore, then that information could not be transferred to that location. At this point, the question to be asked is how many countries in the world have adopted and observed data protection laws? A study conducted in 2012 found that only 89 countries have adopted data protection legislations. ${ }^{31}$ It is not without a doubt that social media platforms are opened to all places and territories where anyone could look up data on individuals. Thus, as a result, no matter how restrictive the data collected in Singapore is, it is still possible to be exposed to territories with little or no data protection laws.

It has to be noted that the Ministry of Education of Singapore has also pioneered digital citizenship education programs in the school curriculum, where primary schools all over Singapore are required to undertake almost 4 hours of cyber wellness education programs every semester. ${ }^{32}$ Along with other agencies, the Singaporean government provides necessary and vital information to effectively inform the children on social media usage and its risks. Since 2012 the Media Literacy Council (MLC) has been formed with members from private and public sectors where they formulate public awareness and educational programs on cyber wellness and address issues on cyber safety and online uncivil behaviour. MLC also advises the government of Singapore on the issues so that policymakers are well informed regarding the risks posed.

31 Graham Greenleaf, Global Data Privacy Laws: 89 Countries and Accelerating, Privacy Laws \& Business International Report, Issue 115, Special Supplement, February 2012, Queen Mary School of Law, University of London LSRP No. 98/2012 (2012). (Retrieved on $20^{\text {th }}$ November 2019) P. N/A.

32 DQ Institute, 2018 DQ Impact Report, Outsmart the Cyber-Pandemic Empower Every Child with Digital Intelligence by 2020, https://www.dqinstitute.org/2018dq_impact_report/ (Retrieved 20 November 2019). 


\section{DISCUSSION AND ANALYSIS}

Overall, the regulatory principles in Malaysian and Singapore are not much different from one another in relation to cyberspace protection for children. Both countries have adopted special legislation on child protection, and have strived to solidify data protection legislation. The age of maturity in Malaysia is fixed as 18 years but in Singapore, a child is a person whose age is below 14 years and a young person means a person whose age is 14 years of age or above but not more than 16 years. In this regard, Singapore legislation provides a more extended defense mechanism in regulating content affecting the children. The governments of Malaysia and Singapore have introduced many legislations that directly or indirectly filter the internet or internet-based media to protect children and take drastic yet swift action against the perpetrators. Similarly, the government of both countries is equally concerned about online safety and child protection.

However, for both countries, ensuring current legislative regulations and policy frameworks on their proper enforcement and implementation is necessary in order to further secure the internet environment. It is critical to have legal protection for children as they are known to be active in some form of online media at any given time. ${ }^{33}$ Malaysia has set up various legislations relating to cyber, which managed to improve the involvement of parents, and to impose liability on them, and to be liable for negligence in relation to the usage of the internet by children. However, in instances where children are victimized on the internet, an amendment of the law is still required to make parental negligence a chargeable offense. MCMC guidelines are indeed adopted by the government to ensure safety for the victims of internet usage, yet more efforts need to be done to bring awareness to these guidelines such as by having it taught as a basic life skill for children, parents, and teachers alike. Also, these guidelines and rules should be updated regularly to keep up with the ever-changing and growing technological advancements.

In the previous studies it has been found that despite Malaysia having sufficient cyber laws, the laws are not adequate to define cybercrimes clearly. In the world of cyberspace, where there are exponential technological breakthroughs on sophisticated methods of

33 Dafna Lemish, Children and Media: A Global Perspective (John Wiley \& Sons, 2015). 13-233. 
circumventing internet protection mechanisms by perpetrators, the laws have to be promulgated in a manner to address these rapidly changing attitudes and tactics. It should be the priority of the government to educate enforcement agencies and to bring awareness to the public on issues related to cyberspace. For this reason, cyberrelated laws should be reviewed and updated regularly.

The overall framework for the protection of children on the usage of the online mediums should also have in mind that along with the implementation of safety mechanisms, internet fair usage and educational usage of the internet should also be given consideration when building the ICT and other relevant digital skills amongst children. ${ }^{34}$ Knowledge is the key to a safe online environment. More focus should be given by the government and relevant authorities in promoting guidelines for internet users to bring them with the latest updates on how to keep up with the ever-growing threat of cyberspace.

\section{CONCLUSION}

This study found that some regulations are already in place in Malaysia and Singapore addressing issues related to the protection of children in cyberspace. However, the area of coverage differs based on cultural and legislative differences where the majority of social networking sites available in Singapore and Malaysia are hosted beyond the reach of the domestic jurisdictions of the two countries. It is found that there are also international conventions such as the International Convention on the Rights of Children to protect children from abuse and unsolicited exposures whilst at the same time seek equal opportunities that are beneficial for children. While protective measures are almost uniform anywhere in the world, the majority of the public is not fully aware of the rights and the protective mechanisms made available to them in order to protect themselves as well as their children from internet abuse. More should be done by the government, internet service providers, and social media companies to inform the public and educate them.

34 Schleicher Andreas, International Summit on the Teaching Profession Helping Our Youngest to Learn and Grow Policies for Early Learning: Policies for Early Learning (OECD Publishing, 2019). 56-72. 